Theatre Research in Canada

Recherches théâtrales au Canada

\title{
Canadian Theatre Made for Black Women
}

\section{Naila Keleta-Mae}

Volume 39, Number 2, 2018

URI: https://id.erudit.org/iderudit/1058048ar

DOI: https://doi.org/10.7202/1058048ar

See table of contents

Publisher(s)

Graduate Centre for the Study of Drama, University of Toronto

ISSN

1196-1198 (print)

1913-9101 (digital)

Explore this journal

Cite this article

Keleta-Mae, N. (2018). Canadian Theatre Made for Black Women. Theatre Research in Canada / Recherches théâtrales au Canada, 39(2).

https://doi.org/10.7202/1058048ar
Article abstract

For close to two decades Trey Anthony has carved out a successful career as a published and produced playwright in Canada in a national theatre landscape where few playwrights enjoy sustained success. This is, in part, because Anthony is also an entrepreneur who identified Black women in Canada as a financially viable and lucrative target market and she has consistently self-produced content that is geared specifically to them. This article begins with the production history, critical response, and box office response to Anthony's play How Black Mothers Say I Love You. It continues with an analysis of the play's content and characters as representative of staging Black female life and it concludes with a contemplation of what Anthony's successful cultivation of a Black female audience in Canada suggests about Canadian theatre.
All Rights Reserved @ Theatre Research in Canada / Recherches théâtrales au Canada, 2019
This document is protected by copyright law. Use of the services of Érudit (including reproduction) is subject to its terms and conditions, which can be viewed online.

https://apropos.erudit.org/en/users/policy-on-use/ 


\title{
Canadian Theatre Made for Black Women
}

\author{
NAILA KELETA-MAE
}

\begin{abstract}
For close to two decades Trey Anthony has carved out a successful career as a published and produced playwright in Canada in a national theatre landscape where few playwrights enjoy sustained success. This is, in part, because Anthony is also an entrepreneur who identified Black women in Canada as a financially viable and lucrative target market and she has consistently self-produced content that is geared specifically to them. This article begins with the production history, critical response, and box office response to Anthony's play How Black Mothers Say I Love You. It continues with an analysis of the play's content and characters as representative of staging Black female life and it concludes with a contemplation of what Anthony's successful cultivation of a Black female audience in Canada suggests about Canadian theatre.
\end{abstract}

En près de deux décennies, la dramaturge Trey Anthony s'est forgé une carrière des plus fructueuses; alors que peu de dramaturges connaissent un succès durable, ses créations continuent à être publiées et mises en scène au Canada. C'est notamment parce qu'Anthony est un impresario qui a su voir que les femmes noires forment un public cible viable et lucratif et qu'elle a toujours produit du contenu qui s’adresse à elles. Dans cet article, Nalia Keleta-Mae présente I'historique de production de How Black Mothers Say I Love You, une pièce d'Anthony, de même que les réactions de la critique et les chiffres de vente. Elle propose ensuite une analyse du contenu et des personnages de la pièce qui représentent le quotidien des femmes noires avant de conclure par une réflexion sur ce que laisse entendre au sujet du théâtre canadien le fait qu'Anthony a réussi à se créer un public fécond chez les femmes noires.

I write for Black women and I'm unapologetic about it and I think that's why my audience comes out-because they know there's a true love affair that happens between us. They love me and I love them because I'm like, "We're in this together girl. You come out and I'm going to give you that experience." We want that experience. (Trey Anthony, July 2016)

This article asserts that Trey Anthony-an accomplished Black, female, queer, playwright based in Toronto and Atlanta-identified a target audience and successfully cultivated that audience through the ways in which she has developed and produced her theatrical work. Anthony's accomplishments are not solely indicative of an altruistic approach to theatre-making, it is also informed by a clear-eyed assessment of the landscape of Canadian theatre and the identification of an underserved demographic with economic means. To 
that end, when mainstage theatres in Canada have declined Anthony's proposals to produce her work, she has self-produced at times to sold out houses. And, when mainstream critical reviews of her work have ranged from positive to unfavourable, she has continued to sell out houses. From my purview, Anthony has done so by producing her plays as what ahdri zhina mandiela calls "cultural events" targeted specifically at her intended audience (Knowles II8).

This article begins with How Black Mothers Say I Love You's production history, critical response, and box office response. It continues with an analysis of the play's content and characters as representative of staging Black female life and it concludes with a contemplation of what Anthony's successful cultivation of a Black female audience in Canada suggests about Canadian theatre.

The "experience" that Anthony asserts is on offer to Black female audience members in the case of her second play, How Black Mothers Say I Love You, is a story set in a home in Brooklyn, New York about a Black mother and her three Black daughters. I specify that her daughters are Black because sometimes Black women have children who do not appear Black. In Black diasporic communities, like the ones that Anthony identifies as her target audience, colourism and shadism are historical and contemporary issues. Another of Anthony's plays-'da Kink in my hair-includes a monologue about the trauma of shadism in said communities by the character Nia, a dark-skinned Black daughter of a Black mother who also had a light-skinned daughter. In other words, in Anthony's work and for Anthony's audience, the extent to which Black characters are perceived as Black in their communities and by society at large is an important component of the story.

Anthony's ability to identify a predominantly Black female audience in Canada as financially viable and then create, and deliver content to them - regardless of mixed mainstream critical acclaim - was first made abundantly clear with the unprecedented success of 'da Kink in my hair which debuted in 200I. And while the structure of Anthony's two published plays differ, there are two notable similarities - the cast is comprised solely of Black Caribbean women living in North America and they take place in locations where Black people gatherthe first in a Black hair salon and the second in a Black home. It is worth noting that both of these settings are places where female blackness can be expressed with minimal direct interaction with the institutionalized anti-Black racism that has existed in North American society for centuries. In other words, Anthony has set both plays in locations that are predominantly Black against the backdrop of Black diasporic life on the continent, which includes and often necessitates being minoritized by dominant culture. This centering of Black space is of particular import with Anthony's work because the contexts of her characters' lives mimics that of her target audience. When Anthony produces one of her plays, attending a performance is akin to attending a "cultural event" where blackness is centered on the stage while the rest of society is kept at bay (Knowles II8).

In How Black Mothers Say I Love You, the protagonist is Daphne, a single, 54-year-old Jamaican woman whose immigration to the US (many years prior to the beginning of the play) was tied to her consenting to labour, upon her arrival, as a domestic worker. At the time of the play, Daphne is terminally ill with cancer, has undergone at least one round of chemotherapy, has lost of all her hair, and has, unbeknownst to her daughters, stopped going to her doctor's appointments. She is a deeply religious, Christian woman with no known lover or spouse. She is also a woman on the brink of death who clutches her bible 


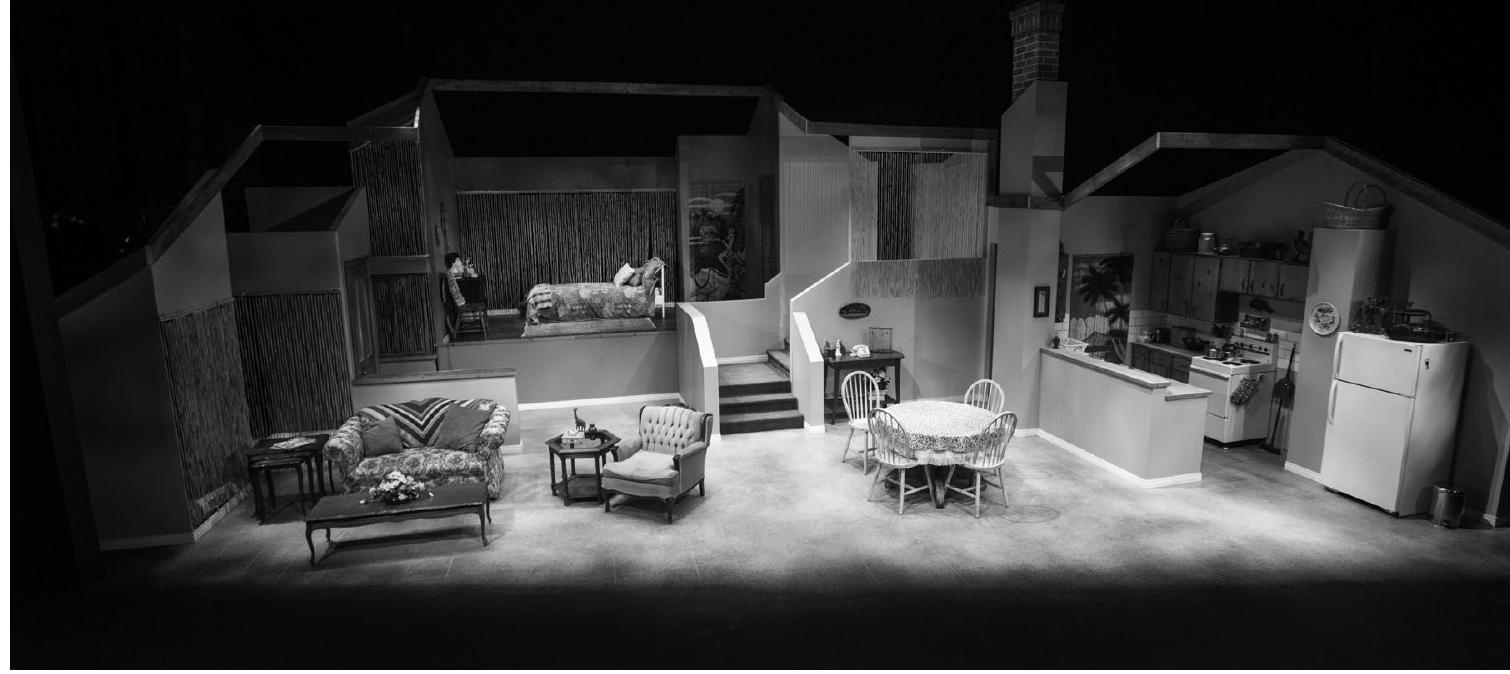

Set of How Black Mothers Say I Love You. Set, Props, and Lighting Designer: Robert Schultz. Costume Designer: Helen Rainbird. Director: Kimberley Rampersad. Great Canadian Theatre Company, March 2018. Photographer: Andrew Alexander

often, references her church community frequently, and espouses orthodox views about abortion, homosexuality, and beauty. Daphne is a storyteller, a woman who leans in close, lowers her voice, and stretches the truth when she wants to indulge in a round of gossip where the behaviour of others is predictably cast as morally inferior to that of the storyteller and listeners.

Her eldest daughter is Claudette, a 37-year-old, liberal-minded social activist and social worker feeling lost after having just broken up with her girlfriend soon after they agreed to deepen their commitment to one another by purchasing a home together. Claudette unexpectedly arrives at her mother's family home with suitcase in hand having just taken a three-month leave from her job in Montreal to be with her mother in her last days. This leave from work comes as a surprise to her family because the last time Claudette was in touch with them was three years prior when she left unceremoniously-seemingly because she had had enough of Daphne's homophobia. Claudette and Daphne's relationship is the central dramatic thrust of the play. Its most significant complication comes from one of the consequences of Daphne's immigration to the US - she left Claudette and her younger daughter Valerie in Jamaica with their maternal grandmother for six years while she attempted to settle abroad. Claudette experienced this separation as abandonment and in this regard How Black Mothers Say I Love You is about the rupture that the illusive pursuit of a better life causes within this female-centered family unit.

The play is an exercise in repetition-over and over again Claudette asks, in some way or another, how Daphne could have left her children behind. Claudette never mentions her father. His absence is a given and is excused by everyone. The children's father, the audience learns, had no financial resources to provide for his children and seems to have been afforded the privilege of having no social expectations or pressures that required him to exercise any other form of parental responsibility. Even as adults, Claudette and her sister do not challenge this gendered notion of parenting or consider the extent to which their mother bore and is expected to bare the brunt of their critiques about the parenting, or lack thereof, that they received. 
DAPHNE: I wanted to get out of Poppa [my father] house so badly that the first man who offered me a candy I took it. Pity is he wanted to give me more than candy and I was too young to know any better.

VALERIE: After you had Claudette you moved out of Poppa's house and went with Daddy?

DAPHNE: Move where? Where was he going to put me? He lived with his mother and seven brothers and sisters. He had a sweet mouth and that's all he had. Promising the moon and stars, and when it came down to it arms and legs too short to grab the moon.

VALERIE: So what did you do? (6I)

Valerie, a 35-year-old woman, is the resident diplomat in the family. At the beginning of the play she is, unbeknownst to her mother, separated from her financially successful white male husband, in couples therapy with him, and contemplating having a baby with him as a means of reconciliation. By the end of the play she and her husband have decided to divorce. The final character in How Black Mothers Say I Love You is the youngest daughter, Cloe, born to Daphne once she settled and married in the US. Cloe was often ill during her childhood and died when she was Io-years-old from sickle-cell anemia. Invisible to her sisters Claudette and Valerie, Cloe haunts the house beckoning Daphne towards death.

Despite its somber theme, How Black Mothers Say I Love You functions primarily as a dramatic comedy replete with generally Caribbean and specifically Jamaican references, tropes, and aesthetics that are traditionally understood as cornerstones of Black women's lives. Most of the action takes place in the kitchen, the running joke is about Valerie's failed cooking, the daughters each negotiate the elder care that their mother requires, and all of this is undergirded by the matriarch's strict sense of religious devotion. In this, and other regards, Anthony has certainly written a play that is designed to resonate primarily with Black women; I would add more specifically with Black women in North America who are reasonably knowledgeable about Caribbean culture.

\section{Part I-Production History}

I, like so many blacks, have been trying to pin myself down in history, place myself in the stream of time as significant, evolved, present in the past, continuing into the future. (Williams 156 )

According to Anthony, the impetus for the play came from her documentation on her iPhone of a conversation she had with her grandmother after she had been diagnosed, like Daphne, with terminal cancer. Anthony had been reading Bronnie Ware's The Top Five Regrets of the Dying: A Life Transformed by the Dearly Departing and asked her grandmother what was her biggest regret. Her Grandmother's response was, "leaving my children behind in Jamaica when I went to England, especially your mother because she has never forgiven me for that" (Anthony, May 20I6). Anthony went on to share the video with her mother, a Black woman whom Anthony had seldom seen cry but who broke down in tears because she had had no 


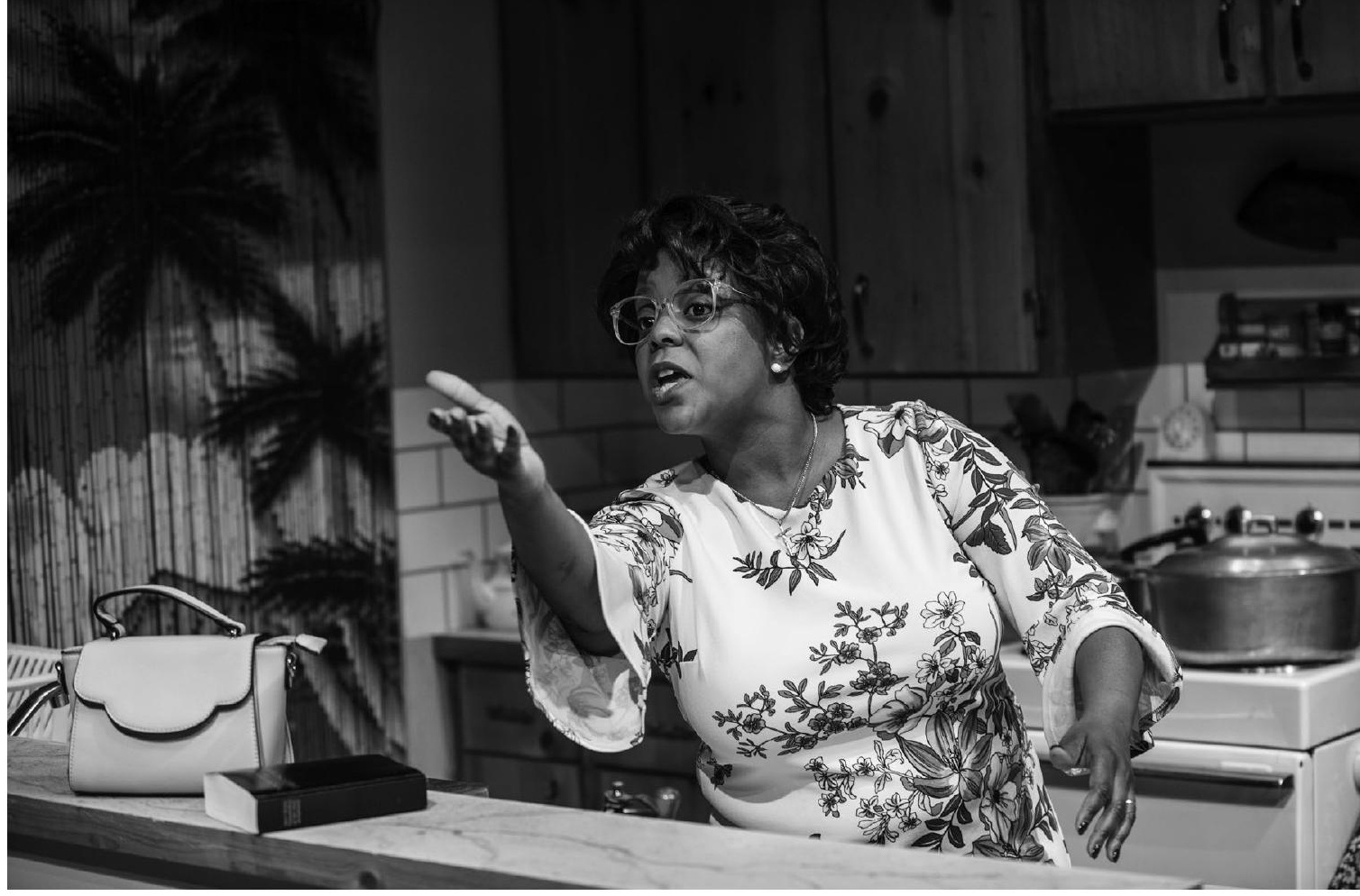

Lucinda Davis as “Daphne.” Photographer: Andrew Alexander

idea that her mother held such profound regret not only about leaving but also about not being forgiven. According to Anthony, her conversation with her grandmother was mediated through an iPhone because "I really had this urgency to capture my grandmother because she was such an integral part of my life" (May 20r6). Anthony's sense of "urgency" and emphasis on the need to "capture" is reminiscent of Patricia J. William's depictions of Black female life in the aftermaths of the TransAtlantic slave trade.

To be without documentation is too unsustaining, too spontaneously ahistorical, too dangerously malleable in the hands of those who would rewrite not merely the past but my future as well. So I have been picking through the ruins for my roots. (Williams I56)

The creation of How Black Mothers Say I Love You can be read as evidence of Anthony sorting through "ruins" - the what's left of Black mother-daughter relationships. These are relationships that are forged on lands like the one known as Jamaica where human and natural resources were and continue to be pillaged to sustain and secure the advancement of colonial and post-colonial empires. These are relationships that are routinely further stretched and stressed as mothers cross sea and ocean to become domestic workers in service of post-colonial domestic needs. This is the terrain of "ruins" (Williams 156) that some Black mother-daughter relationships navigate and the terrain upon which Anthony sets her play.

Anthony went on to repeat and formalize her process of documentation. She interviewed other Black mothers and their daughters with a focus on the same question about sources of regret. Anthony's ethnographic practice can be thought of as a response to the colonial legacies of loss and separation that infiltrate Black life. Somewhat reminiscent of the work 
of the Black American female theatre practitioner Anna Deavere Smith, Anthony wove the ideas and excerpted portions of the text verbatim in her formation of the playscript of How Black Mothers Say I Love You. She also used the footage to create a short film entitled When Black Mothers Don't Say I Love You that screened as part of the 2016 Toronto Black Film Festival during Black History Month, three months before the play's first mainstage production opened at Factory Theatre-with more marketing savvy-on Mother's Day weekend.

I attended a reading of this play at the Daniels Spectrum in Toronto in 20I4. It was directed by Governor General award-winning playwright Djanet Sears and produced as part of a festival by the Toronto-based Black theatre company bcurrent. At the time of the reading, the play was called Black Mothers Don't Say I Love You-a provocative statement that can be read as a commentary on the quality of Black mothers' parenting; especially in an era where parenting has been socialized as an emotive, verbally expressive endeavor. The reading concluded with a talkback with the actors and Anthony-who invited me to the stage to participate when she saw me in the audience. There are three things that I distinctly remember about the reading: the audience was predominantly comprised of Black women; Anthony was focused on asking the audience how they felt about the title; and Anthony was taken by surprise when I asked her why the title was important to her. Anthony seemed genuinely interested in the title's effect on that particular audience and what they made clear that day was that their experience of verbal expressions of motherly love were disparate. Some audience members shared that they had mothers who said "I love you" and that when they became mothers themselves they said those words to their children too. There were also audience members who, like Anthony, had solely experienced motherly love expressed non-verbally. And while the title Black Mothers Don't Say I Love You surmised Anthony's experience it was the anti-thesis of the experiences of some of her audience members. Anthony's commitment to being in conversation with as wide a range of Black diasporic women as possible clearly influenced the development of the play's title. By February 20I6, when the trailer for the short film was released on YouTube, the title of the film and the play had changed to When Black Mothers Say I Love You. A title which, in comparison, minimized the risks of alienating segments of her audience. By the time of the play's opening as a Io-day run at Factory Theatre in May of that same year, the title had changed yet again to How Black Mothers Say I Love You. From my reading, this to-date final, subtle change in wording permitted Anthony to find a title for her work that was no longer a provocative statement but instead an assurance to her audience that the play is an exploration of a statement of fact. In other words, Black mothers do say I love you and the play, and film investigate that truth. Here too, Anthony's emphasis on the how of mothers saying "I love you" can be read as sorting through "the ruins" in search of "roots" which, in Anthony's artistic pursuits, is a widely shared Black female experience (Williams 156). In this case, "the ruins" can be understood as the limitations and denotations of a language that was foisted upon Black people in North America and the Caribbean via the transatlantic slave trade.

When I asked Anthony at the talkback why the then title, Black Mothers Don't Say I Love You, was important to her, I would argue that she was surprised precisely because, though Anthony mines her personal life for dramatic stories, she is primarily focused on connecting that work with the Black women who are her target audience. When talking about the Black women who comprise the majority of her audience Anthony has said, 
I see them. I know them. I love them. They're me. They're my mother. They're my grandmother and that's how I see it. But, I do not take them for granted whatsoever because they can spend their money anywhere and yet they choose to come in a theatre and sit with me and say thank you for putting me up there. (July 20I6)

Anthony directed the play's two mainstage productions at Factory Theatre; one in 2016 , and the other in 2017 . The critical response to both identified the writing as the central point of concern, noting that: it felt like a TV drama (Kaplan); it "fails because the structure that should support the arias is jerry-rigged" (Cushman); or its "expository dialogue between the sisters often feels repetitive and a little too on-the nose" (Maga). In addition to the reading of Black Mothers Don't Say I Love You, I also attended both Factory Theatre runs. In 20I6, I watched a matinée from the balcony along with a house full of high school students and their teachers. This is a demographic with whom I have long-enjoyed attending the theatre because their responses are generally visceral and often not couched in the niceties, social graces, or predictable reverence that at times governs the adult Toronto audiences with whom I have shared theatre houses. In this case, the young people were predominantly Black and of colour. They were vocal throughout the play even, much to my surprise, singing along to several of the popular old Jamaican gospel hymns peppered throughout the production. I had not realized that those hymns were continuing to be passed on. As per usual, Anthony appeared immediately after the play to lead a talkback. Anthony knew beforehand that I would be there and in a moment that I had

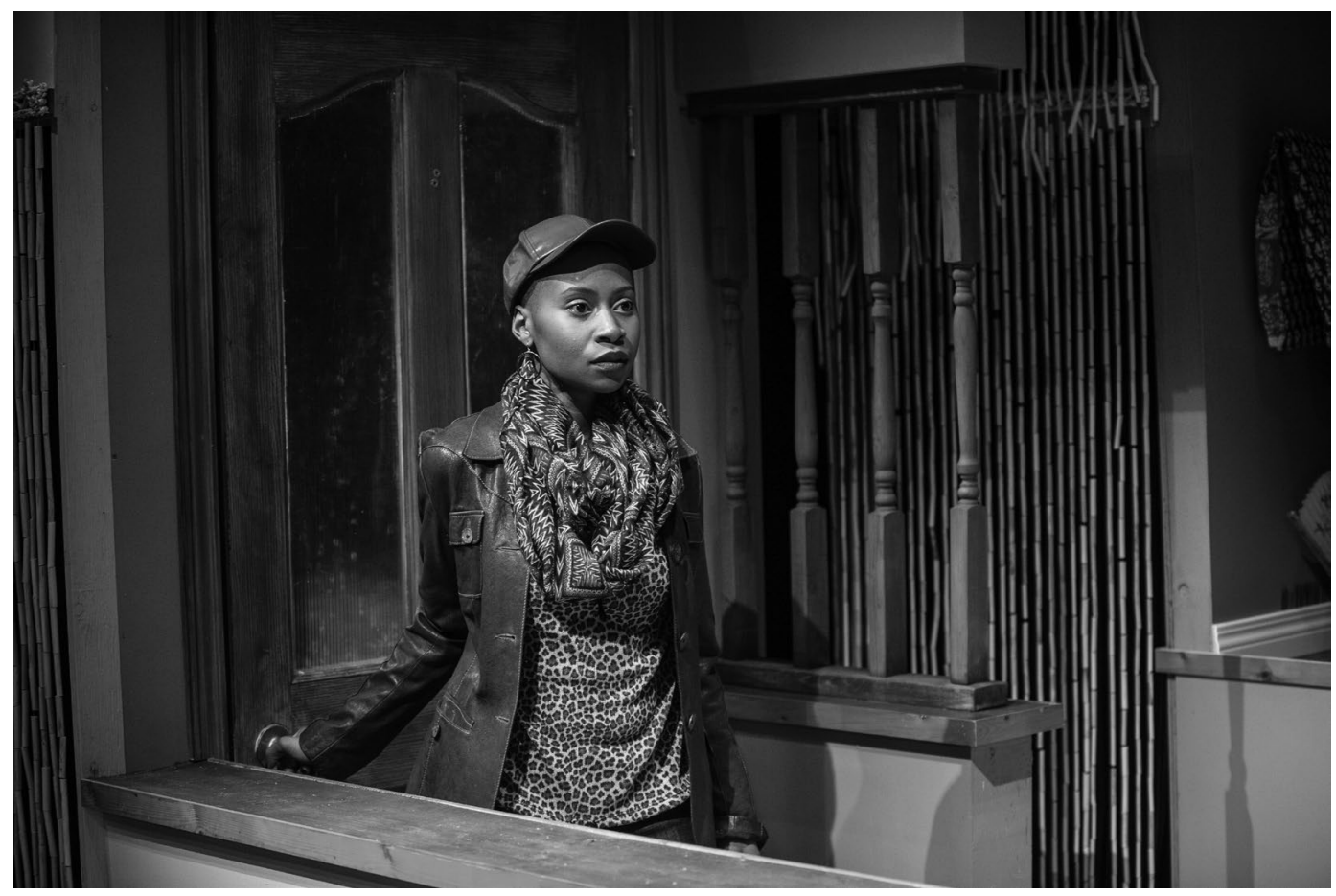

Malube Uhindu-Gingala as "Claudette." Photographer: Andrew Alexander 
not anticipated, she asked me to stand and say the name of my professional title and to list my post-secondary degrees. She said something to the effect that "they need to hear all of it, they need to know it's possible." For Anthony, it seems, the function of the talkback is not only about gaining insights into the audience's reaction to the script, title, and plot but also about creating an opportunity to connect with her target audience or potential future audience (considering the young Black women in attendance that afternoon). To that end, for this specific audience she made her talkback partly a question and answer period and partly an off-the-cuff motivational speech in which she wove her personal story into a larger narrative about pursuing one's dreams. In this regard, she demonstrated to the audience that she is a theatre practitioner who has been where they are, cares about them, and creates events that centre the lives of people like them.

In the fifteen-plus years that I have followed Anthony's work, I cannot recall a play, performance, or event that she has produced that did not include her breaking traditional Canadian conventions of performer-audience relations to directly engage her audience and call them to be involved in her work. At one performance of her first play 'da Kink in my bair at Harbourfront Centre in Toronto in 20II, Anthony came out on stage prior to the beginning of the play to speak to the predominantly Black female audience. She slid easily between English and Jamaican as she humorously informed the audience that they were not to sit quietly and applaud at the end of the play. Instead she expected the audience to be vocal in its support of and disgust with the characters and the story. Her short pre-performance talk included demonstrations and a series of call and response exercises until the audience's initial vocal timidity grew more confident and loud. From my vantage point, the implications of Anthony's intervention in Canadian theatre practices were wide ranging. It signaled to her audience that they were not at a conventional Canadian play where they could mostly passively experience or receive the performance. Instead, they were implicated in its success and were tasked with actively making meaning as it unfolded. Anthony seems to have identified her audience members' personal investment in the work as key to her development of a loyal following. I would go as far as to assert that for Anthony the play, as a medium, is primarily functional. It seems to be the thing that permits her to be in conversation with her target audience and to deepen the "love affair" (Anthony, July 20I6) that she understands them to share. And it is a love affair that consistently garners sold out houses regardless of critics' assessments of the work. Case in point, the 2016 run of How Black Mothers Say I Love You sold out after opening night.

\section{Part II-Staging Black Female Life}

Anthony was born in England to Jamaican parents. When she was nine years old her mother immigrated to Canada in pursuit of career opportunities and left Anthony and her younger brother with their maternal grandmother. It would be three years before the children joined their mother in Canada. In Anthony's family, the pursuit of better opportunities that is tied to leaving the land and people that one knows best is a multi-generational one. Like the eldest daughter Claudette in How Black Mothers Say I Love You, Anthony knows, first-hand, what it means to be left behind. 
Davies and Fido point to "voicelessness" as a key component of Caribbean women's literary output.

The concept of voicelessness necessarily informs any discussion of Caribbean women and literature. It is a crucial consideration because it is out of this voicelessness and consequent absence that an understanding of our creativity in written expression emerges. (I)

As evidenced by the content of Anthony's writing and the aesthetics she employed in her direction of her play's mainstage runs, one of the appropriate ways to engage with her work is to read her as a Caribbean writer addressing voicelessness.

Three of the characters in How Black Mothers Say I Love You have distinctly Black Jamaican names: Claudette, Valerie, and Daphne are widely circulated in Jamaican culture and are generationally appropriate for the ages she's chosen for each woman. Daphne, the mother in the play, is also the name of one of Anthony's Jamaican grandmothers. Cloe, the youngest daughter and the only one born in the US, has an uncommon name for Jamaican culture but one that is quite common in North America - though the spelling that Anthony employs less so. The trajectory of each character can be read as Anthony giving voice to the career and life options available to Black women of the Caribbean diaspora who live in North America. Claudette is a lesbian who broke off an engagement with a man her mother approved of when she was younger and more recently ended a relationship with a woman. She has turned down a promotion that would have led to her doing more administrative, decision-making work in favour of staying in the field and continuing her hands on work with young people. She is a social worker with an affinity for children who have had difficult upbringings. She seems driven to protect them because she feels she was inadequately protected and mothered. By the end of the play Claudette decides, on the fly, to adopt the newborn baby girl of a Black teen mother. Valerie marries into wealth, works for her husband and is devastated when he cheats on her with a young white female intern. Daphne's life revolves around her bible, her gospel music, and her church community; she seems to have abandoned the world beyond those realms. When Valerie implores her mother to tell Claudette that she needs and wants her in her life, Daphne responds:

Tell her that I want her! I carried her for nine months! Pushed her out all on mi own! Take the food out of mi own mouth to feed her. Carry you, me, her, Cloe and the whole world pun mi back! I've done everything and anything! Turned nothing into something for you girls! For what! Huh? For what! What more do you girls want from me? What! Tell me! (softly) I need to tell Claudette I need her? Need her now for what? (66)

I want to spend time here thinking through what it might mean for Anthony, a Black queer female playwright from the Caribbean diaspora who lives in Canada and the US, to "resist, rupture, and disrupt" (Sharpe I3) in the text of How Black Mothers Say I Love You. In In the Wake: On Blackness and Being, Christina Sharpe proposes and defines a "new analytic" for Black studies as "the wake and wake work" that consists of 
[P]lotting, mapping, and collecting the archives of the everyday of Black immanent and imminent death, and in tracking the ways we resist, rupture, and disrupt the immanence and imminence aesthetically and materially. (I3)

The world of Anthony's play is decidedly and recognizably Black. It is one that is devastatingly influenced by the remnants, "the ruins" (Williams 156), the history of slavery and the ongoing acts of anti-Black racism that shaped and shape contemporary Black life in North America. Anthony fills the play with music, humour, and familiar Caribbean tropes. For the Black women in How Black Mothers Say I Love You, queer and heterosexual romantic relationships are irreconcilably lost, failed, or abandoned as a viable option altogether. For these Black women, solitude, and tense family dynamics form the tapestry of their intimate lives. In their world, babies are the central non-religious hope-either through conception as a means to salvage a marriage or through adoption as a means to right perceived mothering wrongs. This, of course, is in stark contrast to the portrayals of "normal" womanhoodread heterosexual, upper middle class, able-bodied, thin and white womanhood - that are authored by content creators who dominate the mainstream in North America.

In Demonic Grounds: Black Women and the Cartographies of Struggle, Katherine McKittrick asserts that,

"normal" places and spaces - of comfort, wealth, peace, safety-are hopefully seductive: they allude to the idea that finding and living the "normal" within existing spatial hierarchies is a geographic achievement, a fulfilling geographic story [...] To challenge something that "just is," as many subaltern subjects have, can be a very threatening geographic act; it is punishable, erasable, and oppositional. (I45)

How Black Mothers Say I Love You certainly challenges "normal" womanhood and what “just is" (McKittrick I45). In Anthony's play, the complex inter and intra personal dynamics or "roots" (Williams 156) that she excavates and stages are presented as facts. There is little sustained lamentation or suggestion that these realities indicate major character flaws or signal failure. In this regard, as a playwright, Anthony refreshingly demonstrates little to no judgment of her characters. Her play paints a picture that is recognizably and empathetically Black - a choice that, in and of itself, demonstrates an act of everyday resistance, rupture and disruption (Sharpe, 13). That said, Anthony's theatrical work is arguably most impactful in her ability to produce specifically for her Black female target market what, in a roundtable conversation about Caribbean Canadian women's theatre, mandiela calls "cultural events" as opposed to "artistic events" (Knowles II8; emphases in original). mandiela draws the distinction thusly: "artistic experiences aren't always social or cultural "events"; artistic experiences lift us out of our everyday, for a moment, a few minutes, or an hour or so" (Knowles I26). From my vantage point, Anthony endeavours to be in conversation with the Black women who attend her productions. They are more than an audience to her and so the cultural events that she produces work against the material constraints of the theatre houses she rents and close the gap of the social constraints of much theatre in Canada that gestures towards topics that do not deal directly with Black life. In other words, Anthony finds ways to convey to her audience that "Yes, we're in this formal theatre space but, this 
is for us, this is for you and me, we can be whatever collective voice we'd like to be in this space." In this regard, it is less about Anthony's independent productions being a sign of clearing space in Canadian theatre or Black diasporic theatre, but more about Anthony tapping into what already exists but, that others have ignored. The audience has long been there waiting to participate. Alison Sealy Smith notes that the expectations of a Black Caribbean audience member are that in a cultural event "you want that experience of your own people celebrating, you get your hairdo, your good shoes, and all of that" (Knowles I26). Rhoma Spencer elaborates that in a cultural event the audience "can talk back, and that in itself is another theatre. You're talking back to the performers on stage and you're engaging them. They [the audience] don't feel like they can do that if they go to Canadian Stage" (Knowles I26).

Samantha Walkes as "Valerie." Photographer: Andrew Alexander

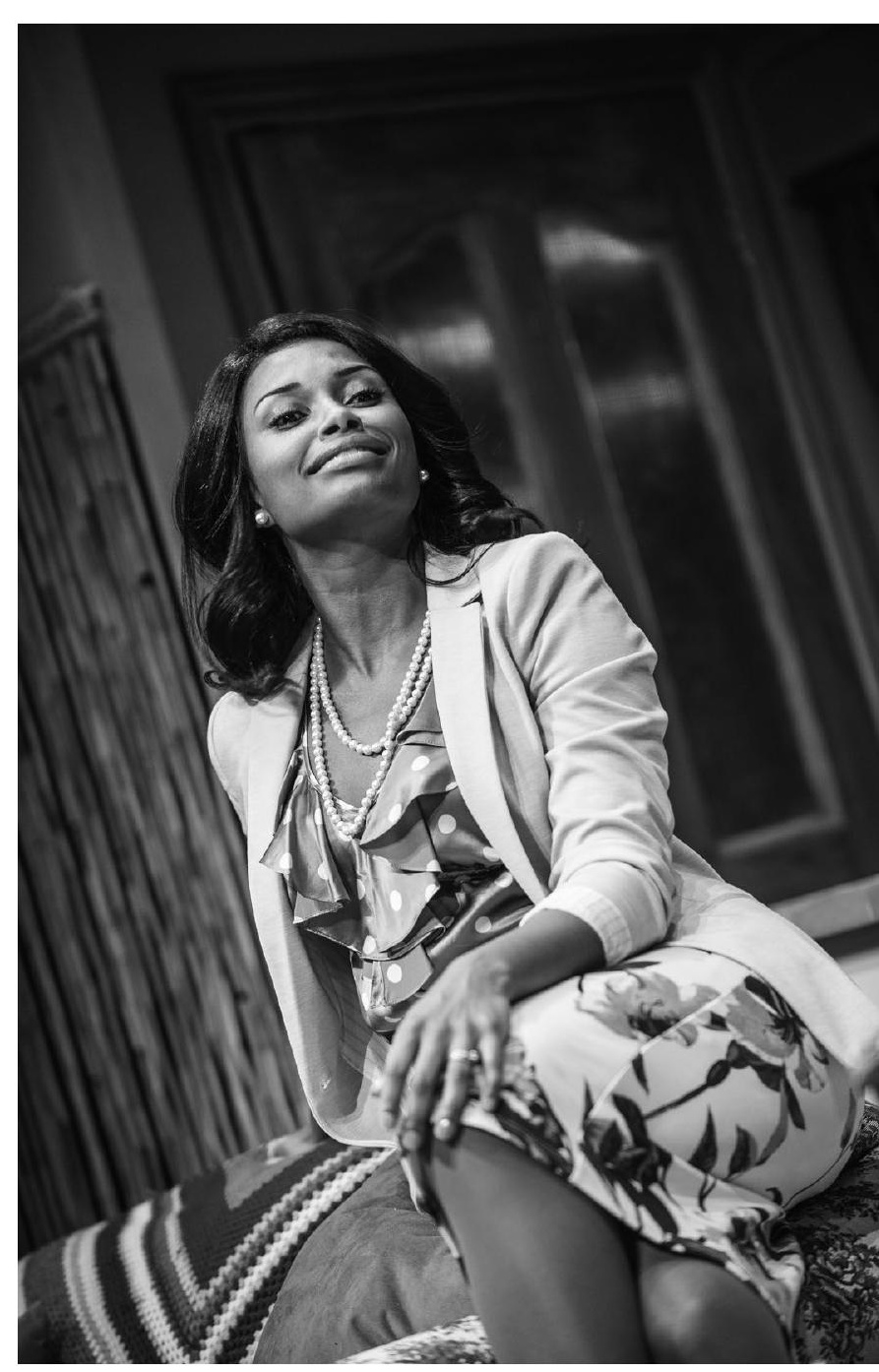


Anthony is widely known primarily as the playwright of the perennially produced and internationally toured play'da Kink in my hair. I saw it when it premiered as a play with box office success at the Tarragon Theatre as part of the Toronto Fringe Festival in 200I. Within two years it played at a couple of Fringe Festivals in the US (Atlanta and New York) and had a run at Theatre Passe Muraille in Toronto. By 2005 it became the first Canadian play staged at the 2000-seat Princess of Wales Theatre in Toronto as part of Mirvish's subscription season where its run was extended five times (nearly three months) and attended by a predominantly Black audience (Young 50-5I). By 2009 'da Kink in my hair had been adapted into a situation comedy and aired at prime time on Global Television for two seasons, making Anthony the first Black Canadian woman to produce a television show that was broadcasted across the nation (DeMara qtd. in Young 5I). It is worth noting that, like How Black Mothers Say I Love You, the critical response to 'da Kink in my hair was mixed at first. It was widely negative by the end and yet, the play's box office success persisted (Young 56). This was also the case with Obsidian Theatre's production of an adaption of Austin Clarke's The Polished Hoe. When that Black Canadian theatre company produced that Black Canadian play for its largely Black audience it was, according to Smith, "an absolute critical failure" (Knowles II8) and yet their houses were ninety per cent full (Knowles iIg).

Not only is Anthony a playwright, comedienne, and actress, she is most formidably an entrepreneur who has identified Black women as a financially viable and lucrative target market and she has relentlessly self-produced content that is geared specifically to them. Anthony is currently writing the screenplay adaptation of How Black Mothers Say I Love You and the film has already been optioned by Conquering Lions Productions with Clement Virgo as the named director. It is worth noting that for years Anthony has stated on social media that she is inspired by Oprah Winfrey's business acumen and Tyler Perry and Tarell Alvin McCraney's theatre to film models.

\section{Part III-Not All Canadian Theatre Audiences Are Dying}

We hear about how Black people don't come out to theatre and then we also hear about the theatre audience dying in Canada...We have a sold out run. We opened one night and the whole run is sold out and it's predominantly a Black female audience who continue to come out in droves and support my work because they see themselves. We all are hungry to see ourselves. We want to know that we're actually validated, that our experiences are real and for me that's why I write because I so want to know that I can go somewhere and see myself. And if it's not happening, if mainstream media doesn't feel that my experience is validated [sic] or needs to be validated then I need to create that for myself. (Anthony, July 20i6)

Even a cursory examination of the history of theatre in Canada reveals the systemic erasure of the theatre practitioners and theatrical practices that are tied to Indigenous peoples, Black people, and people of colour. These institutionalized omissions are perhaps most glaring in the nation-building project of the 1949 Royal Commission chaired by Vincent Massey. The Massey Commission, as it became known, included nation-wide consultations 


\section{Bénédicte Bélizaire as "Cloe." Photographer: Andrew Alexander}

and subsequent recommendations (Rubin $173-80$ ). There was, however, no meaningful attention to the artistic practices of the Indigenous Peoples, Black people and people of colour whose presence, on the land now known as Canada, in some instances predated the formation of the nation itself. I would argue that one of the persistent repercussions of these systemic omissions and erasures is most visible in the demographics of the audiences that routinely attend the country's large-scale theatres and the demographics of the students who attend theatre programs across the country. There have and continue to be an array of substantive and superficial efforts by institutions, theatre companies, scholars, and publishers to right these historical wrongs. There have been sustained efforts to accurately reflect the breadth of theatre makers and traditions that inform the dramatic works that take place across Canada. And yet, the challenges persist, in large part because the Massey Commission is the foundation of formalized theatrical practices in Canada and the legacies of the Commission are structural. Much like any building, once the foundation is poured and the above-ground structure built it is difficult, but certainly not impossible, to change it.

What is particularly compelling about Anthony's plays How Black Mothers Say I Love You and 'da Kink in my hair is that both texts and production histories make clear that the playwright is not preoccupied with creating work that will fall into the illusive category of the 
universal or that will be legible and interesting to non-Black theatre audiences in Canada. As Anthony noted,

I'm tired of going to diversity conference after diver[sity conference]...I don't even show up anymore because I have nothing left to say. Instead of talking about it let's actually put things into actions. And so that's why I self-produce. This is why I have my own following because I don't wish to talk about it anymore. I'm like "Let's just do it. Let's get on with it already." (July 20I6)

The development of How Black Mothers Say I Love You included Anthony's stay at the Banff Playwrights Lab, initial drafts read by the late dramaturge Iris Turcott (Anthony, How Black Mothers i), and Anthony's time as an artist-in-residence at Canadian Stage (Anthony, July 20I6). According to Anthony, when she approached Canadian Stage about producing the show they turned it down, as did three other mainstage theatre companies in the country (Anthony, July 2016). Is any theatre company obligated to produce any work? Certainly not. But, it is noteworthy that a playwright whose past work ('da Kink in my hair) enjoyed extraordinary box office success was unsuccessful when she shopped around a then new play (How Black Mothers Say I Love You) that had undergone a recognizable development history. In the end, Anthony successfully self-produced her new work because a mainstage theatre in Canada would not.

In "Speaking in Tongues: Dialogics, Dialectics, and the Black Woman Writer's Literary Tradition," Mae Gwendolyn Henderson asserts that " $[t]$ he self-inscription of Black women requires disruption, rereading and rewriting the conventional and canonical stories, as well as revising the conventional generic forms that convey these stories" (30). Anthony's primary audience is Black women and she has created sold out "cultural events" for them, since at least 200I, demonstrating that Black women in Canada are a viable niche market for theatrical works and production modes that disrupt, reread, and rewrite (Henderson 30) representations of female blackness on stage. The play whose title revisions have settled on How Black Mothers Say I Love You, was created by a playwright invested in dramatizing specific sets of experiences to a specific group of people. The play was produced by a playwright whose connection with her audience was strong enough that she could successfully mount a play regardless of mainstream media's critical response or the production interests of large-scale theatres in the country. In August 2018, there was a reading of How Black Mothers Say I Love You at Joe's Pub Public Theater in New York directed by the Tony-award winning Broadway and film director Kenny Leon. One of the hashtags Anthony used in her social media campaigns to mobilize her audience was \#broadwaybound. Only time will tell but Anthony's goal is clear as was one of the pictures of the reading that circulated online (D. Anthony). In it, Anthony is doing one of the things that she has consistently done to make her productions cultural events that allow her to build and connect with her audience to establish and deepen their "love affair" (Anthony, July 20r6). In the picture, Anthony is standing centre stage, addressing the audience while the cast and director wait behind her.

For close to two decades Anthony has, undeniably, carved out a career as a published and produced playwright in a national theatre landscape where few playwrights enjoy sustained success. Anthony continues to expand her audience and her network in ways that seem to solidify her trajectory of consistently circumventing Canadian theatre practitioners', 
scholars', and administrators' perennial concerns about dwindling numbers in theatre audiences and theatre students in Canada.

\section{Work Cited}

Anthony, Darren. “At Joe's Pub at The Public.” Facebook, 3r Aug. 2018. Web. I2 Sep. 2018. Anthony, Trey. How Black Mothers Say I Love You. Toronto: Playwrights Canada Press, 2017. Print.

---. "Struggling to Say I Love You." The Agenda with Steve Paikin. YouTube, 5 July 2016. Web. I9 Feb. 2018.

---. "Trey Anthony on Why Some Mothers Struggle to Say 'I Love You.” 2. CBC Radio, 4 May 20I6. Web. I8 Feb. 2018.

Cushman, Robert. "How Black Mothers Say I Love You Isn't Actually Boring, but it Conveys an Exaggerated Belief in its own Effectiveness." National Post, I4 Feb. 20I7. Web. I9 Feb. 2018.

Davies, Carole Boyce and Elaine Savory Fido. "Women and Literature in the Caribbean: An Overview." Out of the Kumbla: Caribbean Women and Literature. Trenton, New Jersey: Africa World Press, 1990. I-24. Print.

Henderson, Mae Gwendolyn. "Speaking in Tongues: Dialogics, Dialectics, and the Black Woman Writer's Literary Tradition.” Changing Our Own Words: Essays on Criticism, Theory, and Writing by Black Women. Ed. Cheryl Wall. New Brunswick: Rutgers University Press, 1989. 16-37. Print.

Kaplan, Jon. "Review: How Black Mothers Say I Love You Scores Laughs and Tears." Now Magazine, Ir May 2016. Web. 22 Feb. 2018.

Knowles, Ric. "Having a Whole Lot of Show Going On: Diasporic Caribbean Theatre in Toronto." Theatre Research in Canada 38.I (2017): II2-27. Print.

Maga, Carly. "How Black Mothers Say I Love You Captures Lingering Familial Strain.” Toronto Star, 9 May 20I6. Web. 2I Feb. 2018.

McKittrick, Katherine. Demonic Grounds: Black Women and the Cartographies of Struggle. Minneapolis: University of Minnesota Press, 2006. Print.

Rubin, Don. Canadian Theatre History: Selected Readings. Toronto: Playwrights Canada Press, I996. Print.

Sharpe, Christina. In The Wake: On Blackness and Being. Durham: Duke University Press, 2016. Print.

Williams, Patricia J. "On Being the Object of Property." Writing on the Body: Female Embodiment and Feminist Theory. Ed. K. Conboy, Nadia Medina, and Sarah Stanbury. New York: Columbia Press, 1997. 155-75. Print.

Young, Harvey. "Plaitform Concerns: Trey Anthony's 'da Kink in my hair." New Canadian Realisms. Ed. Roberta Barker and Kim Solga. Toronto: Playwrights Canada Press, 2012. 50-67. Print. 